\title{
Recent Developments of Health Insurance in West Germany
}

\author{
by J.-Matthias Graf v.d. Schulenburg*
}

\section{Introduction}

Looking at the political debate on the state and the future of the health care systems in our modern societies we will find three major goals proclaimed by politicians, providers and consumers. Firstly, the system should allow equal access to health care facilities for all citizens. This can be called the solidarity goal because it implies a comprehensive social health insurance scheme covering the health care costs of all. Secondly, competition and prices should ensure efficiency and the best allocation of scarce resources in medical care. If we want price competition, then providers must have the freedom to lower prices or increase them in case of a demand surplus. Thirdly, especially providers call for freedom of choice. Everybody should be able to choose that physician or hospital he or she prefers.

Unfortunately, as Table 1 indicates, all of these three goals cannot be achieved at the same time. If one wants to achieve solidarity and equal access to health care, this implies comprehensive health insurance at the same time. However, then one has to sacrifice the freedom of pricing and quality determination for the suppliers or limit the freedom of choice for the patients. Otherwise, as the first model in Table 1 indicates, no cost control is feasible bescause the contervailing power principle is abolished.

The second alternative outlined in Table 1 is characterized by comprehensive insurance coverage freedom of choice but no price competition. Prices for medical services are given by negotiated fee schedules, per diem rates or other statutory pricing rules. In principle, this alternative is chosen by the fathers of the German statutory health care system.

The advocates of a pro-competitive-strategy, however, prefer the third alternative of having a number of compeding insurance plans or Health Maintenance Organizations. In principle, providers are then free to charge any price. However, HMO-members may only consult a doctor who is under contract with his or her HMO. If a provider is too expensive, the HMO will exclude him from providing care for its members. Although, there exist strong sympathies especially among German health economists for developing the German system in this direction, the chances of reforms to initiate HMO-type organizations are

* International Institute of Management, Berlin and Munich University; paper presented for the Geneva Association in Paris, on December 4, 1986. 
currently very low (cf. Hauser/Schulenburg, 1987). The German physicians' associations as well as the sickness funds' associations are strongly against a reform increasing competition among health service suppliers and insurers or opening the system for HMO-type organizations. To sum up, if you want solidarity and price competition you can not have freedom to choose the health care supplier at the same time.

Table 1: The Dilemma of Health Care System Modeling

\begin{tabular}{|c|c|c|c|c|}
\hline $\begin{array}{l}\text { Solidarity } \\
\text { Equal } \\
\text { access }\end{array}$ & $\begin{array}{c}\text { Competition } \\
\text { Freedom of } \\
\text { pricing and } \\
\text { determining the } \\
\text { quantity }\end{array}$ & $\begin{array}{l}\text { Freedom of } \\
\text { choice }\end{array}$ & $\begin{array}{c}\text { Cost } \\
\text { control }\end{array}$ & $\begin{array}{l}\text { Type of } \\
\text { system }\end{array}$ \\
\hline yes & yes & yes & no & $\begin{array}{c}\text { what everybody } \\
\text { wants and } \\
\text { does not work }\end{array}$ \\
\hline yes & no & yes & $\begin{array}{l}\text { by negotiations, } \\
\text { price and } \\
\text { quantity } \\
\text { regulations }\end{array}$ & $\begin{array}{c}\text { statutory } \\
\text { health care, } \\
\text { scheme, e.g. } \\
\text { Germany }\end{array}$ \\
\hline yes & yes & no & $\begin{array}{l}\text { by negotiations, } \\
\text { barriers } \\
\text { to entry }\end{array}$ & $\begin{array}{l}\text { HMO-type } \\
\text { insurance } \\
\text { scheme }\end{array}$ \\
\hline no & yes & yes & $\begin{array}{c}\text { by } \\
\text { market } \\
\text { forces }\end{array}$ & $\begin{array}{l}\text { Chicago-school: } \\
\text { pure market } \\
\text { system }\end{array}$ \\
\hline
\end{tabular}

The advocates of a pure market allocation of medical services, however, raise the question why we should base our system on solidarity at all. They view health services as "normal" goods and therefore do not see any resons for a statutory or national health insurance scheme. This leads to the fourth alternative presented in Table 1.

Because : "National health insurance is an . . example of misleading labeling. In such a system there would be no connection between what you would pay and the acturial value of what you would be entitled to receive, as there is in private insurance. In addition it is not directed at insuring "national health" - a meaningless phrase - but at providing medical services to the residents of the country. What its proponents are in fact proposing is a system of socialized medicine". (Friedman/Friedman, 1981, 104). In addition, why should the government care for cost control in medical care? This ". . . can be dismissed out of hand at least until someone can find some example of an activity that is conducted more economically by government than by private enterprise. As to the first, the people of the country must pay the costs one way or another... Private insurance arrangements are available to meet the contingency of an unsually large expanse". (Friedman/Friedman, 1981, 104,5). 
In this paper we will show, that the German system is mainly characterized by the second alternative of health care system modeling, as described Table 1. Equal access is guaranteed by a very comprehensive statutory health insurance scheme, covering more than $90 \%$ of the population. Only for pharmaceutical products the first alternative was approached, with a disastrous result. Co-payments and other measures were necessary to control prices and quantities of drugs prescribed by doctors. Under the impression of rapidly increasing health care costs and the modern deregulation movement, reform proposals advocate to modify the German system in the direction of the third and fourth alternative described in Table 1. The paper is organized as follows : Firstly, we will give a general overview about the German health care scheme. Secondly, we will explain in more detail the remuneration of providers. This section contains remarks about ambulatory care, hospital care and pharmaceutical products. The last section addresses the solidarity problem.

\section{General Overview of the German System}

\subsection{Historical Development}

Most characteristic of the German system is the statutory sickness fund (Gesetzliche Krankenkassen), whose genesis was an address by the Emperor Wilhelm I. to the Reichstag in 1881. As of June 1883, when the Health Insurance Act came into effect, blue-collar employees - and later other members of the population - had to be insured by one of the numerous sickness funds. Accordingly, the statutory health care scheme became the oldest part of the social security system, followed by the acts concerning accident insurance (1984), retirement funds (1889), public assistance (1924), and unemployment insurance (1927). Contributions, benefits, and other components of the statutory sickness funds are regulated in detail by the second code of the Social Insurance Act (Reichsversicherungsordnung, or RVO), the first draft of which dates from 1911.

After World War II, the West German ligislature enacted numerous statutes concerning public health care; the most important of these resulted in the founding of the Federal Department of Health and Human Service in 1961. The government established statutory fee-schedules for physician services and dentist services in 1965 revised in 1982; specified employer's liability for cotinued payment of wages in case of illness (Lohnfortzahlung); and created the Medical Profession Education Law (Approbationsordnung) in 1970. Also important were the 1972 law concerning the financing of hospitals (Krankenhausfinanzierungsgesetzt), and the disputed Health Insurance Cost Containment Law (Krankenversicherungskostendämpfungsgesetz) of 1977 , which was followed by the second Health Insurance Cost Containment Law of 1982. With these regulations the German health care system became the most regulated sector in the entire economy (see for a detailed description Glaser [1978], Landsberger [1981], Reinhardt [1981], Stone [1979, 1980]).

\subsection{Cost Trends}

The German health policy discussion is dominated by controversy over reasons for the explosive increase in health care expenditures and proposals to stem spiralling costs.

Table 2 shows the health care cost as a percentage of GNP for two very different health care systems : the heterogenous U.S. system and the solidarity type system adopted in West Germany. The most striking characteristic of the German expenditure growth is 
Table 2: National Health Expenditures as a Percentage of Gross National Product

\begin{tabular}{cc|c} 
Year & U S A & F.R. Germany \\
\hline 1970 & 7.6 & 6.4 \\
1975 & 8.6 & 9.1 \\
1980 & 9.4 & 9.2 \\
1985 & 10.8 & 9.5 \\
\hline
\end{tabular}

Source : National Health Expenditures 1983, Health Care Financing Review, Winter 1984; Müller, W., Ausgaben für Gesundheit, Wirtschaft und Statistik 9 (1986), 791-797.

the rapid increase from $6.4 \%$ of GNP in 1970 to $9.1 \%$ in 1975 , and the leveling off since then. The cost explosion in the early seventies might have been due to the social reform policies of Social-Democratic Chancellor Willy Brandt (who came into power in 1969) and to the relative increase in the number of elderly people.

In 1973 an intensive public discussion on the cost of medical care was initiated by Heiner Geissler (1973) who has been later Federal Secretary of Health and Human Services followed by Rity Süßmuth. The formerly moribund sickness funds discovered the power given them by the Social Security Act, and insisted on conditions that would allow stable contribution rates (in percentage of income). A public campaign and studies at the sickness-fundfinanced research institute, WIDO, in Bonn provided support. As a result, regulatory measures taken by the state and federal governments produced the Health Insurance Cost Containment Law in 1977, which introduced expenditure gaps on ambulatory medical care as well as on prescribed drugs (Arzneimittelhöchstbetrag). But it is quite possible that the public discussion of the problem and the reorientation of the sickness funds' self-understanding were actually more important than the Cost Containment Law (and earlier regulatory measures) in stopping the escalation of medical costs.

Table 3 : Health Care Expenditure by Sources (in \%)

\begin{tabular}{l|r|r|r} 
& \multicolumn{2}{c}{1970} & 1980 \\
\hline public households & 14.1 & 13.4 & 13.3 \\
statutory sickness funds & 34.7 & 45.1 & 46.4 \\
statutory pension funds & 9.5 & 7.8 & 8.4 \\
statutory accident insurance & 3.6 & 3.2 & 3.3 \\
private health insurers & 5.1 & 4.5 & 4.9 \\
employers & 24.6 & 19.2 & 15.9 \\
private households & 8.4 & 6.8 & 7.8 \\
\hline
\end{tabular}

Source: Wirtschaft und Statistik 9/1986. 
Although the statutory sickness funds dominate the German health care scheme, they cover less than half of the national health care expenditures, as it can be seen from Table 3 . However, the share and the influence of the statutory sickness funds have increased significantly in the past.

\section{Price Control}

\subsection{An Overview}

As mentioned in the introductory section, a comprehensive third party coverage and freedom of choice requires price control mechanisms. To understand the German system of price control one has to remember two things : First, more than $90 \%$ of the German population are covered by one of the numerous statutory sickness funds providing full coverage for ambulatory hospital and dental care. Therefore, we will shortly explain the statutory sickness fund scheme. Secondly, there is a sharp disctinction between ambulatory physician care and hospital care. Office-based physicians do not normally have hospital privileges. Hospital-based physicians operate on a salary basis, and their salaries are covered by the per diem rates negotiated between the sickness funds and the hospitals. Only private patients (i.e. patients who are not covered by a sickness fund or public assistance) have to make additional payments for physician services in a hospital.

\subsection{Office-based Physicians}

In West Germany, office-based physicians play the dominant role in the health care sector as a whole. Every patient who is covered by a statutory sickness fund must first consult a physician in order to receive any type of medical care. Only office-based doctors may provide ambulatory care, prescribe drugs and medical appliances, and decide who is to be hospitalized. If the case is not an emergency, the hospital requires a referral order written by an office-based physician before the patient may be treated.

During the period 1960 to 1984 , the number of physicians, and especially the number of office-based physicians, has increased rapidly (see Table 4). This amounts to 2.6 physicians per 1,000 inhabitants which is a higher physician-population ratio than in most other countries. The number of physicians is expected to increase even more rapidly during the next years. This is due to the increased number of medical students and the stew age-distribution of office-pased physicians. Less physicians will retire during the next decade then before. In 1970 only 4,400 students were registered at medical schools as first year-students. Till 1983 this number increased to 11,350 . Up till now the medical associations have nearly no control over the medical schools because these are part of the German state universities financed by general taxes. This rapid increase in physicians, the so-called "Ärzteschwemme", has led to more competition among physicians and decrease of their relative income. Between 1980 and 1984 the number of office-based physicians increased by $9 \%$ but the number of cases decreased by $1 \%$, so that physicians had to suffer an average loss of $9.2 \%$ of patient-cases. Although physicians have the ability to create demand for their services by increasing the number of physician-contacts and services per case (see Kraft/Schulenburg, 1986), their relative income droped over the past few years (see Table 5). 
Table 5 : The relative income of office-based physicians

\begin{tabular}{c|c} 
& \multicolumn{2}{|c}{ Average Physician Income* } \\
\cline { 2 - 2 } & Average Income of all Employees \\
\hline 1967 & 6.1 \\
1971 & 6.4 \\
1975 & 5.7 \\
1979 & 4.6 \\
1983 & 3.9 \\
1986 & 3.7
\end{tabular}

* net income (professional expenses deducted) before income taxes

Source : Own calculations based on data from the Statistisches Bundesamt and Zentralinstitut für die Kassenärztliche Versorgung.

To stem these developments the medical association as well as the sickness fund association have proposed a cut down of students at medical school, a longer training for young physicians, and a more difficult licensing procedure for foreign physicians. The federal government has recently enacted a decree that physicians have to pass a significant longer period of training at a hospital before they may open their own office.

Table 6 and 7 provide some more information about the medical profession in the Federal Republic of Germany. During the past few years the number of foreign physicians has increased significantly. Most of these foreign physicians have studied medicine in Germany and have then succeeded in staying in Germany. People from countries belonging to the European Community (EC) do not need a labor permit in Germany. However, the number of physicians from EC-countries is still relatively low due to the restrictive licening procedure.

While in 1952 only $34 \%$ of the office-based physicians were specialists, this proportion had increased to $56 \%$ by 1982 . A major reason for this increase is a financial one, since general practitioners or family doctors are not permitted to provide patients with many of the services which have relatively high fees (such as electrocardiograms, electroencephalograms, and x-rays). In spite of the increase, the percentage of specialists in the U.S. remains much higher than in West Germany. Unlike in the U.S., group practices are rare in Germany : in 1975 , only 2,301 physicians (about $4 \%$ of office-based physicians) worked in the 1,131 existing group practices.

In the twenties, the statutory health insurance scheme was in great disorder. Therefore, Chancelor Brüning enacted an emergency decree in 1932, shortly before Hitler came into power. By this decree, medical associations, KV (Kassenärztliche Vereinigungen), were founded in each state and every office-based physician treating sickness-fund patients had to join the KV in his state. Since then, the remuneration of physician services 
has been subject to negotiation between the sickness funds and the KV. It is important to note that no direct negotiations or contacts take place between individual physicians and sickness funds. Physicians receive payment from their KV, which in turn is compensated by the sickness funds. The medical associations and the dental associations were very sucessful in their negotiations with the sickness funds so that physicians belong to the highest income classes of society, although their relative income position has decreased as it is shown in Table 5. It is interesting that dentists outstrip the physicians, and are now in the position of the income pyramid. This is mainly due to the relatively constant number of dentists (see Table 6) and the increase of the expenditure for denture. These are nearly fully covered by the sickness funds since 1975.

Table 6: Active Physicians and Dentists in the Federal Republic of Germany

\begin{tabular}{lrrrr}
\hline & 1960 & 1970 & 1980 & 1984 \\
\hline $\begin{array}{l}\text { Physicians } \\
\text { total number }\end{array}$ & 79,350 & 85,801 & 118,726 & 156,593 \\
per 100,000 population & 142 & 163 & 211 & 255 \\
percent office-based & $62 \%$ & $51 \%$ & $45 \%$ & $44 \%$ \\
percent hospital-employed & $29 \%$ & $39 \%$ & $46 \%$ & $47 \%$ \\
percent in admin. \& research & $9 \%$ & $10 \%$ & $9 \%$ & $9 \%$ \\
Dentists & & & & \\
$\quad$ total number & 32,509 & 31,175 & 32,958 & 33,713 \\
per 100,000 population & 58 & 51 & 54 & 56 \\
percent office-based & $97 \%$ & $95 \%$ & $94 \%$ & $94 \%$ \\
\hline
\end{tabular}

Source: Statistisches Bundesamt, Statistisches Jahrbuch, Wiesbaden 1964-1985.

Table 7: Personal Characteristics of German Physicians (December 31, 1984)

\begin{tabular}{|c|c|}
\hline $\begin{array}{l}\text { Total number of physicians } \\
\text { - general practitioners } \\
\text { - specialists } \\
\text { - female physicians }\end{array}$ & $\begin{array}{r}156,593 \\
67 \% \\
33 \% \\
27 \%\end{array}$ \\
\hline $\begin{array}{l}\text { age under } 35 \\
35-39 \\
40-49 \\
50-59 \\
60-65 \\
\text { over } 65\end{array}$ & $\begin{array}{l}25 \% \\
16 \% \\
23 \% \\
12 \% \\
14 \% \\
14 \%\end{array}$ \\
\hline $\begin{array}{l}\text { Foreign physicians } \\
\text { - EC-countries } \\
\text { - other European countries } \\
\text { - Africa } \\
\text { - Asia } \\
\text { - America } \\
\text { - others }\end{array}$ & $\begin{array}{r}14,4 \% \\
36,3 \% \\
6,4 \% \\
32,7 \% \\
4,8 \% \\
5,4 \%\end{array}$ \\
\hline
\end{tabular}

Source: Arnold, M. et al., Der Beruf des Arztes in der Bundesrepublik Deutschland, Köln : Deutscher Ärzte Verlag; Bundesärztekammer 1985. 
As mentioned above, all office-based physicians are compensated by a uniform fee schedule. Since technical services have relatively high fees compared with personal physicians' services, specialists who provide more technical services obtain higher income. Table 8 shows the average incomes and professional expenses differentiated by specialization. Radiologists have by far the highest income while pediatricians are at the bottom of the income scale. This is why a new fee-schedule is currently developed by the physicians' association, which will be implemented in October 1987. Till 1989 sickness funds pay a lumpsum to the physicians' association which is then distributed to the physicians according to their relative number of services provided.

Table 8 : Average Income of Office-based Physicians by Spezialisation

\begin{tabular}{l|cc|cc}
\hline & \multicolumn{2}{|c|}{$\begin{array}{c}\text { Average net income* } \\
\text { (German marks) }\end{array}$} & \multicolumn{2}{c}{$\begin{array}{c}\text { Professional expenses as } \\
\text { percentage of gross income } \\
\end{array}$} \\
\hline 1975 & 1983 & 1975 & 1983 \\
\hline general practioner & 144,105 & 140,691 & 40.2 & 52.6 \\
internist & 181,028 & 155,952 & 46.0 & 59.0 \\
gynecologist & 159,993 & 133,745 & 39.0 & 56.9 \\
pediatrician & 116,260 & 151,067 & 42.6 & 54.3 \\
opthalmologist & 186,264 & 196,206 & 35.6 & 45.5 \\
otolaryngologist & 131,057 & 160,765 & 42.2 & 49.1 \\
surgeon & 131,782 & 161,222 & 49.8 & 60.3 \\
radiologist & 269,139 & - & 56.5 & - \\
urologist & 173,470 & 157,393 & 47.6 & 62.0 \\
neurologist & 144,033 & 212,336 & 40.2 & 47.5 \\
\hline
\end{tabular}

${ }^{*}$ Before tax, professionel expenses deducted

source: Statistisches Bundesamt, Fachserie 2, Reihe 1.61 Kostenstruktur bei Ärzten, Zahnärzten, Tierärzten, Stuttgart, Mainz. Schulenburg, J.-M. Gf., Systeme der Honorierung frei praktizierender Ärzte und ihre Allokationswirkungen, MohrSiebeck : Tübingen 1981, 57.

\subsection{Hospital Care}

There are three characteristics of German hospital care which dominate the current discussion : (1) the relatively long length-of-stay, (2) the financing of hospital care and the explosive increase in hospital care expenditures; and (3) the governmental planning of hospital facilities (Krankenhausbedarfsplanung).

Problem 1 : The relatively long length-of-stay. A major reason for the relatively long length-of-stay in German hospitals is the sharp delimitation between the ambulatory care provided by office-based physicians and hospital care. This is because most hospitals are prohibited from offering out-patient care, even when the patient has previously been 
hospitalized. A committal order written by a private physician is required in order for a patient to receive hospital care. Both because of the poor flow of information between private and hospital physicians, and because office-based physicians do not have access to the (usually superior) hospital equipment, hospitals repeat many diagnostic examinations already performed by private physicians prior to hospitalization; in fact, such duplication is more the rule than the exception in Germany. Other medical examinations which could be done before hospitalization are a standard part of hospital treatment itself in Germany, adding to length-of-stay and, ultimately, to cost of stay. And the sharp delimitation between ambulatory and hospital care has another effect, too : patients stay longer in hospitals because hospital doctors, unsure about the nature of medical care after the discharge, prefer to keep a patient in the hospital until a complete recovery has been made.

The solution to the above problem seems very simple : hospitals should have the possibility of providing outpatient care; and private physicians should be granted access to hospital facilities and allowed to provide hospital care. The powerful German Medical Associations, however, succeeded in 1977 in hindering the passage of legislation that would have enabled necessary measures (such as an amendement to the Social Insurance Act) to be taken.

A second reason for the relatively long length of hospital stays in Germany seems to be the lack of incentives under the present hospital financing scheme for hospitals to shorten the length-of-stay, as it is explained in the following paragraphs.

Problem 2: The Financing of Hospital Care. The financing of German hospitals, is regulated by federal law : the Hospital Financing Act of 1972 and 1985 (Krankenhausfinanzierungsgesetz or KHG) and the Hospital Care Rating Decree of 1973 (Bundespflegesatzverordnung or BPV). These laws replaced and standardized former regulations, which were inadequate in various aspects.

The principle components of current arrangements for hospital financing are that (1) capital expenditures are totally financed by state budget funds; (2) the hospital's current costs (i.e., operating costs) must be financed by per diem payments, either from the sickness fund or the patient; (3) per diem rates must be fixed in such a way that they enable the hospital to cover all current costs of management. (These rates are uniform for all patients, but may differ among hospitals). Capital expenditures are defined by law as the construction costs of a hospital plus the costs for durable equipment (articles 2 and 3, $\mathrm{KHG}$ ). A precondition to receive federal budget funds is that the hospital meets certain standards and conforms to the Hospital Need Plan (Krankenhausbedarfsplan), wich is discussed below.

Per diem rates are set annually by the individual states and are differentiated by hospital groups according to the criteria listed in the BPV (articles 11 and 16). Prior to this, each hospital calculates its average cost per bed-day in a form specified by the decree (Selbstkostenblätter). On the basis of this calculation, the sickness funds negotiate per diem rates with the individual hospitals. If they reach an agreement, the state government will follow it when setting the per diem rates (though it does not have to do so). Otherwise, the state government decides hospital rates on its own. On the one hand, hospitals have a legal claim to receive cost-covering rates. On the other hand, the sickness funds refer to article 17.1 BPV, which demands economical hospital management. Therefore, it is not unusual to find in Germany that sickness funds as well as hospitals sue to change the stated rates. 
This system of setting the rates on the basis of historical costs leads to great discrepancies in the rates.

The hospital financing scheme described above has an inherent problem : clearly there is no economic incentive for hospitals to shorten the length-of-stay. Patients are frequently hospitalized on Fridays and often discharged on Mondays, even though no specific medical care is provided on weekends. The hospital financing system offers no incentive to reduce costs and to use resources economically, because the per diem rates are calculated on the basis of past cost data. The higher the costs of Hospital care in the past, the higher the present rates will be.

Other forms of financing hospitals such as degressive per diem rates, or diagnostic related group type of financing (DRG) - are being discussed in Germany, but seem to be unacceptable to all concerned.

Problem 3: Planning for Hospital Needs. The Hospital Financing Act restricts federal funds for capital expenditures to those hospitals which have received accreditation. Combining hospital accreditation and financing was intended to achieve three major goals :

(1) A more equitable regional distribution of hospital facilities and available hospital beds.

(2) A well-balanced regionalized structure of hospitals.

(3) A reduction in the number of hospital beds with a concomitant increase in occupancy rates.

The German hospital-need planning implies some obvious problems. First, the act contains no clear criteria or standards for states' hospital planning; therefore, the criteria underlying the Hospital Need Plans differ from state to state or are not indicated explicitly at all. Second, it turns out that, in practice, hospital-need planning affects only construction of new hospitals or additions to already existing ones. A hospital which is once listed in a Hospital Need Plan can hardly be expelled from the plan. This is the reason why hospitalneed planning can only change the structure and distribution of hospital care in the long run. Finally, it is now very difficult for private hospitals to become accredited : only $4 \%$ of the hospital beds are under private ownership; thus hospital-need planning seems to have paralyzed the private sector.

\subsection{Pharmaceutical Care}

The sickness funds spend about $15 \%$ of their entire expenditure for drugs and medical appliances. This is more than for dental care and denture and nearly as much as for ambulatory physician care $(18.3 \%)$. Two causes could be named for these extraordinarily high expenditures : excessive consumption and high prices. German Surveys indicate that German doctors prescribe on average about 11 medicines per person per year - almost three times than their American colleagues. Surprising also is the finding that about $60 \%$ of all medicines prescribed in Germany are prescribed primarily at the request of the patients; furthermore, doctors declare that $40 \%$ of prescriptions are unnecessary, ineffective, or even noxious. One reason for the relatively large consumption of drugs by German patients might be the coverage of prescribed drugs by sickness funds and by most private health insurers. 
The German legislature's contribution to lowering drug expenditures was the passage in 1977 of Article 368 of the Social Insurance Act. This article mandated the creation of a black-list (Negativliste) of drugs normally used in the treatment of "trifling illnesses" (Bagatellerkrankungen). These drugs would then be paid for out-of-pocket by the patient and would no longer be covered by sickness funds, even when they were prescribed. In addition the co-payments for prescribed drugs were increased several times and are since $1983 \mathrm{DM}$ 2.00 per prescribed medicine.

In addition to large per capita consumption of pharmaceuticals, high prices also play an important role in determining the level of expenditures for drugs. A more analytical look reveals that the demand side of the drug market involves three distinct sets of actors : physicians, who decide what should be consumed but bear no portion of the cost; patients, who consume the drugs but decide neither what to consume nor how much to pay; and the sickness funds, who foot the bills but exercise not control over what is consumed. This three-way partition in deciding, consuming, and paying creates a situation in which market forces can hardly determine drug prices. A comparison of drug prices in West Germany and other countries underscores this dilemma (see Schulenburg (1983), 344).

During the last years the government took two steps to revitalize more price competition in the drug market. First, the parliament created a Drug "Transparency" Commission (Transparenzkommission am Bundesgesundheitsamt). Its task is to publish and distribute lists (Transparenzliste) comparing prices of medical compounds with the same uses and/or ingredients. Second, the Medical Association and the sickness funds are compelled by law (Art. 368e, 6 RVO and KVKG of June 6, 1977) to negotiate yearly an overall ceiling on drug expenditures (Arzneimittelhöchstbetrag). The Medical Association must then influence its members by moral suasion, prescription guidelines, and other measures to implement the negotiated ceiling.

\section{Solidarity}

As major goal of the German health policy is, as mentioned above, to achieve equal access to health care for all citizens covered by the scheme. This does not necessarily mean that all groups of the society have the same health services consumption level. Income, education and ethnical heritage play important roles for health services utilization even if it can be achieved by no monetary cost.

Facing the difficulties to control prices and quantities and to restrict the freedom of choice for patients, a more market-oriented health care system is proposed by politicians, economists, providers and employers. This should be adopted by a significant increase of out of pocket payments. Along these lines the government has imposed a deductible of 5 to 10 German marks per hospital day (with a maximum of 70 to 300 German marks p.a.) and has increased the co-payments for prescribed drugs and denture. A further increase of costsharing arrangments is proposed by the Federal Department of Social Affairs. It is currently working on a major reform of the German health care system, the so-called "Strukturreform". However, German health-insurers will not be allowed to turn into HMO-type organizations. 


\section{REFERENCES}

CAMERON, C.M., SCHULENBURG, J.-M. GRAF v.d., "Quasi-Markets - A Third Approach toward Cost Containment?" Paper presented at the Association of Public Policy Analysis and Management conference, Minneapolis, 29 October 1982.

FRIEDMAN, B.M. and R., Free to Choose, New York: Avon Books 1981.

GEISSLER, H., Krankenversicherungs-Budget, Mainz: Regierung Rheinland Pfalz 1973.

GLASER, W.A., Health Insurance Bargaining: Foreign Lessons for Americans (New York : Gardner Press, 1978), 95-116.

HAUSER, H., SCHULENBURG, J.-M. GRAF v.d. (eds.), Health Maintenance Organizations eine Reformkonzeption für das deutsche Gesundheitswesen,(Gerlingen : Bleicher, 1987, forthcoming).

KRAFT, K., SCHULENBURG, J.-M. GRAF v.d., Co-insurance and Supplier-induces Demand in Medical Care : What do we have to Expect as the Physician's Response to Increased Out-ofpocket Payments?, Journal of Institutional and Theoretical Economics 142 (June 1986), 360-379.

LANDSBERGER, H.A., The Control of Cost in the Federal Republic of Germany. Lessons for America? Department of Health and Human Services, Publ. No. (HRA) 81-14003, February 1981.

REINHARDT, U.W., "Health Insurance and Health Policy in the Federal Republic of Germany", Health Care Financing Review 3 (December 1981), 1-14.

SCHULENBURG, J.-M. GRAF, Report from Germany : Current Conditions and Controversies in the Health Care System, Journal of Health Politics, Policy and Law 8 (Summer 1983), 320-351.

STONE, D.A., "Health Care Cost Containment in West Germany", Journal of Health Politics, Policy and Law 4 (Summer 1979), 176-199.

STONE, D.A., The Limits of Professional Power : National Health Care in the Federal Republic of Germany (Chicago : University of Chicago Press, 1980). 